\title{
OECD DAC 원조효과작업반 및 집행위원회 결과
}

$\mathrm{OECD}$ 개발원조위원회(DAC) 산하 원조효과작업반 회의가 2009.12.2 4간 파리 OECD 본부에서 개최되어 원조효과 제고를 위한 파리선언, 아크라행동계획(AAA) 이행 촉진 및 2011년 서울 원조 효과고위급회의(HLF-4) 준비방안 등을 논의하였다. 동 회의에는 외교부, 기획재정부, 주OECD대 표부, KOICA, 수출입은행으로 구성된 대표단이 참석하여 아래와 같이 회의 주요 내용을 정리 및 보고하였다.

\section{I. 핵심요지}

\section{1. 주요 논의내용}

파리선언 및 아크라행동계획(AAA)의 이행을 촉진하기 위해서는 개도국의 개발수요에 초점을 맞추고 기 존 원조 체제를 활용하는 이행계획 수립과 실질적 이행확보를 위한 노력 제고가 필요함. 원조효과작업반 의 클러스터 및 작업팀 활동이 불필요한 문서작업보다는 총체적으로 회원국 본부 및 수원국 현지에서의 원조효과 제고 노력을 지원하는데 초점을 맞추는 것이 중요.

2011년 제4차 원조효과 고위급회의(HLF-4)의 성공적 개최를 위해서는 수원국, 공여국, 시민사회 등 다 양한 이해관계자와의 폭넓은 협의를 거쳐 HLF-4 비젼 및 아젠다 설정, 체계적 준비체제 수립 등의 필요 성이 강조됨.

아크라 HLF-3의 경험에 비추어 HLF-4 Roadmap을 조기 수립, 투명하고 포괄적인 준비 프로세스를 확 보하는 것이 필요하며, 변화된 개발환경 하에서 파리선언 및 $\mathrm{AAA}$ 이행 등 원조효과 제고 노력을 종합 평 가하는 한편, 개발 효과성 모색, 글로벌 원조체제 등 정치적 아젠다를 발굴하고 Post-PD 시나리오를 검 토할 필요가 있음. 또한 유엔 $\mathrm{DCF}$ 등 주요 개발 회의와의 연계를 강화하여 시너지를 제고하는 것과 홍보 활동의 중요성이 강조되었으며, 이에 따라 $\mathrm{HLF}-4$ 홍보 프레임 수립을 위해 한국, UNICEF, 가나, 아프 
리카개발은행, 홍보전문가 등이 참여하는 홍보 집행위원회(executive committee)가 구성될 예정임.

\section{2. 대표단 원조효과작업반 회의참석 내용}

대표단은 파리선언 이후의 아젠다 발굴 등을 위해 2010년 G-20 정상회의 개최이후 HLF-4 준비회의 성 격의 '글로벌 원조체제에 관한 워크샵’ 개최를 제안하고 회원국들의 지지와 참여를 촉구함. 이를 통해 다 양한 개발주체를 포괄하는 글로벌 원조체제 모색, 변화하는 개발환경하에서 HLF의 적실성 제고, HLF-4 준비과정에 작업반 비회원국을 포함한 다양한 이해관계자들의 참여 촉진을 위한 기회 제공 기대.

파리선언 및 $\mathrm{AAA}$ 이행을 위해 필요한 기존 원조체제 조정, 제한된 역량 등을 고려하여 각 국가들이 benchmarking할 수 있는 상황별 구체적인 사례발굴 필요성을 제기하고 관련 사무국 및 클러스터 작업을 촉구함.

\section{II. 상세 내용}

\section{1. 원조효과작업반 전체회의}

\section{가. 파리선언(PD) 및 $\mathrm{AAA}$ 이행 촉진}

개도국의 개발수요 중심 및 국별 $\mathrm{PD} / \mathrm{AAA}$ 이행 지원에 초점을 맞춘 클러스터 활동 중요성 및 클러스터 활 동간 연계강화 필요성이 강조됨. 단계별 $\mathrm{AAA}$ 이행계획 수립 및 기존 체제 활용이 필요하며, 본부와 현지 사무소간 커뮤니케이션 제고 중요. 상호 학습(peer-learning)을 촉진하고 국별, 지역별 노력을 연계하기 위한 지역차원의 이니셔티브가 강조됨.

수원국 그룹(Caucus group)은 파리선언 및 AAA 이행관련 다음의 우선순위 제시: 원조일치(수원국 시스 템 사용, 개발 정책 · 전략 반영 등), 원조의 예측가능성 제고, 상호책임성(mutual accountability) 및 개 발성과 관리, 변화된 원조조건(conditionality) 부여(정책적 조건이 아닌 결과중심의 조건부여), 원조조화, 원조분절(aid fragmentation) 개선 및 거래비용 축소, cross-cutting 목표로서 역량개발 강조.

\section{나. HLF-4 비젼}

구체적인 사례발굴을 포함한 실증적, 종합적인 원조효과 제고 노력이 평가됨. 변화된 글로벌 원조체제, 개발환경하에서 원조효과성 논의의 적실성, 역할 등이 논의되었고, 원조효과 제고 활동이 기여한 개발 효 과 제시 필요성이 제기됨. 파리선언 이후의(Post-PD) 시나리오 검토 등 개발 효과성 등 정치적, 미래 지 
향적 새로운 아젠다 모색검토.

\section{다. 콜롬비아 남남협력 고위급회의}

2010년 보고타 남남협력 고위급 회의는 남남협력 모범사례 발굴, 원조효과 제고 관련 개도국의 기반 강 화, 향후 계획 수립을 목적으로 개최 예정.

\section{라. 글로벌 원조체제에 관한 워크숍}

당 대표부는 작업반 전체회의에서 글로벌 원조체제를 모색하고 파리선언 이후의 아젠다 발굴을 위해 2010년 하반기 또는 2011년 초에 HLF-4 준비회의 성격의 글로벌 원조체제에 관한 워크숍(Workshop on evolving global aid architecture) 개최를 제안하고 회원국들의 지지와 참여를 촉구함.

\section{2. 원조효과작업반 집행위원회(ExCom)회의}

\section{가. 국별 AAA 이행 촉진}

의장단은 수원국 현지에서의 실질적 필요, bottleneck을 파악하고, 어떤 지원이 필요한지 논의하기 위해 2 개 정도의 수원국을 방문하여 다양한 이해관계자와 협의하는 방안 제안.

\section{나. 예산 운영}

수원국의 회의 참가 경비 지원 등 관련 원조효과작업반의 예산 부족문제에 대해 각 클러스터가 먼저 스스 로 문제를 파악해서 해결방안 모색하도록 함. 클러스터 활동에 대해 공동 우선순위(collective priority)를 선정하고, 회원국이 국내 예산확보 프로세스에 반영할 수 있도록 전체적인 HLF-4 예산계획을 조속히 수 립할 필요가 있음이 제기됨.

\section{다. Communication strategy}

홍보전략 프레임워크 수립을 위한 executive committee를 구성하여 다양한 홍보대상(정치가, 전문관료, 일반 대중)별 홍보전략을 수립키로 합의함.

\section{라. Milestones to $\mathrm{HLF}-4$}

2011년 HLF-4전에 예정된 주요 개발 회의 결과를 정치적 모멘텀 제고 등을 위해 효과적으로 활용하기 위한 커뮤니케이션의 중요성이 강조됨. $\mathrm{HLF}-4$ 개최 시기 관련 10 월 중순-11월 중순에는 예산수립을 위 한 국내 프로세스 문제로 수원국 각료급 참석이 어려울 수 있음을 고려할 필요가 있음. 


\section{마. 지역회의}

원조효과에 대한 인식, 정치적 모멘텀 제고 등을 위해 파리 외 지역에서 원조효과작업반 지역회의, $\mathrm{ExCom}$ 등을 개최하는 방안 논의함.

\section{III. 관찰 및 평가}

우리의 DAC 가입을 평가하며 $\mathrm{HLF}-4$ 개최 등을 통해 원조효과 제고를 위한 한국의 적극적 역할에 대 한 높은 기대가 관찰됨. 유엔, G-20 정상회의 등에서의 주요 관련 논의를 유기적으로 활용하여 2011년 $\mathrm{HLF}-4$ 가 국제사회 개발협력 노력의 전기를 마련하기 위해서는 원조효과작업반의 HLF-4 Roadmap 수 립에 적극 기여하는 한편 포괄적, 전략적인 우리의 $\mathrm{HLF}-4$ 준비계획을 조속 수립하고 범정부적 준비체제 발족 필요

파리선언 및 $\mathrm{AAA}$ 의 체계적 이행을 위한 행동계획을 수립하는 국가가 확대되고 있으며, 2011년 초에 파 리선언 및 $\mathrm{AAA}$ 이행 모니터링 및 평가가 실시될 예정인 바, 주요 관계부처· 기관이 참여하는 $\mathrm{AAA}$ 이 행계획을 조속히 수립하고, 원조체제 개선 및 개발역량 강화를 시급히 추진 필요. 특히 HLF-4 개최국으 로서 원조효과에 관한 정치적, 대중적 인식 제고 및 지지기반 확대를 위한 홍보활동을 위해 홍보 집행위 (communication executive committee)를 조속 출범시키는 등 적극적 역할 수행 필요

우리가 추진하고 있는 글로벌 원조체제에 관한 워크숍이 HLF-4 아젠다 수립에 기여할 수 있는 의미있는 성과를 도출하기 위해서는 주요 이해관계자를 포함하는 논의 그룹을 구성, concept paper 작성 등 관련 논의를 활성화시켜야할 것으로 판단됨. 특히, 중국, 인도 등 신흥공여국의 적극적 참여를 확보하기 위해 개발분야 협력관계를 구축하기 위한 노력 강화 필요. 